\title{
OBITUARY FOR ENRIQUE HÜLSZ PICCONE (1954-2019)
}

BY ÓSCAR PALACIOS BUSTAMANTE

It is now my duty to note and inform with great sorrow of the unfortunate loss of Enrique Hülsz Piccone, Mexican philosopher, internationally distinguished scholar, eminent professor of numerous generations, jazz and blues musician, playful friend, devoted father and beloved husband, who passed away on February 13, 2019.

Enrique Hülsz Piccone studied Philosophy at the Faculty of Philosophy and Literature (FFyL) of the National Autonomous University of Mexico (Universidad Nacional Autónoma de México, UNAM), where he taught and conducted his researches on ancient Greek and Latin philosophy since 1978. Awarded by his alma mater for his outstanding academic performance, he was a member of the Seminar in Metaphysics of the same University founded and held by the Mexican-Catalan philosopher Eduardo Nicol, whose philosophy was in many senses crucial to Hülsz Piccone's work, life and generation.

In 1989, on the occasion of the Second Symposium Platonicum, Enrique Hülsz Piccone co-founded the International Plato Society, supported by the C. J. de Vogel Foundation. The next year he received the French-Greek philosopher Cornelius Castoriadis at the UNAM, whose conversation with the students was later translated and published by Hülsz Piccone under the title Diálogo con Cornelius Castoriadis.

Hülsz Piccone was the author of a large number of papers, commentaries, book reviews and lectures. His work is mainly a continuous and vigorous investigation of the problems, meanings and forms of expression found in the so-called pre-Socratic tradition, the works of Plato and Aristotle, and the Hellenistic com- 
mentators, all of which is written with extreme philosophical and philological rigour, rich in elegance and a fresh, vivid style.

Enrique Hülsz Piccone was, no doubt, the most important scholar in the Spanish speaking field of ancient Greek philosophy, particularly because of his researches on Heraclitus of Ephesus. His major book Logos: Heraclito y los origines de la filosofia, published in 2011, has become, in this sense, paradigmatic.

As a highly productive editor, translator and organizer of philosophical events, he collaborated with a significant network of scholars from all over the world. An example of this is the book Nuevos ensayos sobre Heráclito, an edition of the proceedings of the Second Symposium Heracliteum, organized by Hülsz Piccone himself and held in June 2006 in Mexico City. He was also a Council Member of the International Association for Presocratic Philosophy (IAPS), which he co-founded in 2008 .

His last publication is an article on a new emendation of a corrupted Parmenidean verse (DK28 B1.3), which he and the philologist Bernardo Berruecos co-wrote in honour of the Argentinian philosopher and philologist Néstor-Luis Cordero. Even if Hülsz Piccone had already published a critical edition of the fragments of Heraclitus, in collaboration with the Spanish philosopher José Gaos in 1982, it must be mentioned that Enrique Hülsz Piccone left an edition and a new translation of the fragments of Heraclitus, which will be published by his editor and friend Mauricio López Valdés as a posthumous work.

The profound and vast knowledge as well as the charming and elegant style of his dialogical teaching turned him into a Master who had the equal respect for people, philosophical texts of any tradition, poems, languages, songs and films. Enrique Hülsz Piccone personified a singular choice of balance between philosophy and life. This singularity is, at the same time, an irreplaceable loss and the joyful privilege of a heritage.

Gracias, Enrique. Descansa en paz.

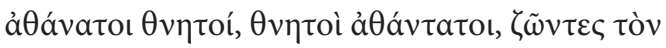

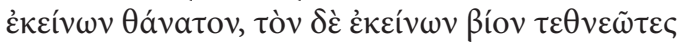

Heraclitus of Ephesus

DK22 B62 